URBAN ŠEBJAN, Ph.D. ${ }^{1}$

E-mail: urban.sebjan@um.si

POLONA TOMINC, Ph.D. ${ }^{1}$

(Corresponding author)

E-mail: polona.tominc@um.si

KARIN ŠIREC, Ph.D.1 ${ }^{1}$

E-mail: karin.sirec@um.si

1 University of Maribor, Faculty of Economics and Business

Razlagova 14, 2000 Maribor, Slovenia
Human - Transport Interaction

Preliminary Communication

Submitted: 14 June 2016

Accepted: 10 Apr. 2017

\title{
MULTIPLE CONCEPTUAL MODELLING OF PERCEIVED QUALITY OF IN-FLIGHT AIRLINE SERVICES
}

\begin{abstract}
Despite growing literature on the different aspects of airline service quality in relation to behavioural intentions, less attention has been paid to some specific aspects of in-flight services. The focus of the present research is, therefore, on a multiple conceptual model of the quality of in-flight services in relation to passengers' perception of value, followed by recommendations (word of mouth - WOM) of airlines, as well as the quality and comfort of airline seats. The study is performed using two databases of reviewers'/passengers' opinions regarding the quality of in-flight airline services and airline seat comfort. Our research results reveal that the perceived comfort of the airplane seat is the most important factor of passengers' perceived quality of in-flight airline services, which also considerably affects the passengers' perception of value, and consequently moderates behavioural intentions (in our research, expressed through positive WOM). The analysis of the relative importance of the components of perceived airline seats' comfort shows that seat width is the most significant factor that contributes to the overall perceived comfort of the airline seat.
\end{abstract}

\section{KEY WORDS}

in-flight airline service quality; perceived value; recommendations (word of mouth); airline seat comfort;

\section{INTRODUCTION}

The growth of globalization today gives air transport an ever more important role. In the past two decades, the air travel industry has faced significant changes reflected in higher quality standards, various pricing strategies, and growth of air transport traffic, among other changes [1]. According to the 60th Edition of the International Air Transport Association (IATA) World Air Transport Statistics (WTS) for 2015, the yearbook of the airline industry performance, in 2015 world airlines carried 3.6 billion passengers on scheduled services; an increase of $7.2 \%$ over 2014 , representing an additional 240 million air trips. In addition, airlines transported 52.2 million tonnes of cargo [2].
Although the global economic performance remains a concern, the strength of the economic cycle will play a key role in the continuous expansion of demand growth for air travel in 2017. However, experts warn that the questions over the durability of the economic upswing, rising oil prices [3], financial crisis in Greece, recent weakness in regional trade activity in the Asia-Pacific area, and the renewed terrorism threats and continued geopolitical tensions have the potential to dampen the performance on these markets [2]. These are all reasons that further encourage the examination and monitoring of air travel services. The growing competition, rising demand, and described potential threats require constant delivery of high-quality services within the airline industry. Simultaneously, continuous improvements are essential for airline profitability and sustained development. Therefore, a better understanding of the relationship between determinants affecting passenger's service quality perception, their perceived value, and consequently their behavioural intentions are of the utmost importance, and the focal point of the present research.

Researchers have studied various dimensions of airline services quality from the passenger's perspective, most of which investigated passengers' perception of airline service quality in relation to their behavioural intentions, taking into consideration the theory of airline services value, price, feedback, and passenger satisfaction $[4,5,6,7,8]$. Since transport service is a chain process, passengers' air travel experiences can be observed from the perspective of airport ground services and in-flight services [1]. The latter has gained considerably less attention among researchers. That is why the present study pays attention to specific areas, such as in-flight airline services quality in relation to perceived value and passengers' recommendations (word of mouth - WOM) (which, in our case, is regarded as a proxy for passengers' behavioural intentions), as well as passengers' perception of airline seat comfort. The quality of airline seats 
is also emphasized in Chen and Chang's [9] analysis, which found that seat comfort was the first priority for improvement. It has been found that passengers consider the comfort of their seats as an increasingly important service item [10]. To date, researchers have paid less attention in studying the specifics of the relationship between the quality of in-flight services in the airline industry and passengers' airline recommendations or with the specific dimensions of the quality of airline seats. In order to fill this gap, the described phenomena are being addressed in this study. These research areas are particularly important for airlines and organizations engaged in the development of aviation services and products. For airlines to improve their market position, they need to improve their competitive advantages, where positive WOM can play an important role. But in order to achieve both, they first need to invest in improving the quality of specific inflight services in order to improve passengers' value perception. Therefore, a multiple conceptual modelling approach was developed, established, and verified based on in-flight airline service quality with the specific attention being paid to the perceived quality of airline seats, which prove to be the most influential factor when assessing the perceived value for money.

The study is based on two research models whose objectives are to determine: (i) the impact that perceived quality of in-flight airline services has on the service perceived value, and consequently on passengers' airline recommendations, and (ii) the relative importance of components of perceived airline seats comfort for passengers.

\section{THEORETICAL BACKGROUND AND HYPOTHESES DEVELOPMENT}

\subsection{Components of airline service quality}

Quality represents an important dimension of any provided service, and the aviation industry is no exception. The concepts of service quality, service quality measurement, and service quality management have been a focal point for researchers since the early 1980s [11, 12, 13, 14, 15], and it continues to gain importance and usefulness as a result of intense market dynamics. Quality is clearly a vital key to customer-perceived value creation, customers' satisfaction, and loyalty $[16,17]$. Quality is mostly dependent on perceived competence, responsiveness, and empathy of the people with whom customers interact [18].

Rhoades [19] argues that the "reality" of airline service quality is that it is at its highest when the industry is experiencing economic difficulty (recession, high fuel prices, terrorism threats, etc.). Numerous studies have addressed service quality issues in the airline industry. Regarding the quality of airline services, security is of utmost importance, regardless of whether they are low-cost airlines or full service carriers. Passengers expect an appropriate quality of all services in proportion to the amount paid for the flight ticket, but high safety and security-related quality levels are obviously a must in either case, and passengers will not be willing to compromise on this aspect [20]. Other researchers have found that passengers consistently rank "assurance" as the most important service dimension [21]. Convenience of service is also important in a passenger's choice of airline. This implies that airlines should improve various aspects of convenience, e.g., ease in purchasing tickets, baggage handling, or flight times [22]. Wittmer et al. [23] found that management of customers' value poses special problems in the context of the aviation industry, because airlines are subject to various consumer-related factors (e.g., socio-demographic characteristics, involvement) and situation-related factors (e.g., time pressure, peer-group pressure, etc.).

Researchers studied the quality of airline services in terms of airline-tangible and terminal-tangible aspects, empathy, schedules, services provided by ground staff, services provided by flight attendants, reliability, responsiveness, and assurance $[4,8,24$, 25, 26, 27, 28, 29]. Passengers are concerned with both; the physical and empathy aspect of the service; results show that the courtesy of attendants, safety, seat comfort, and responsiveness of attendants are among the top four service quality criteria [10].

The above literature review shows that service quality has been mostly examined independently in ground/airport service settings and on in-flight service settings [9]. The current study focuses specifically on the in-flight service quality.

\subsection{Perceived value and passengers' airline recommendations}

Researchers have also often studied perceived airline service quality in relation to passengers' behaviour intentions. Common belief is that higher service quality can lead to a higher overall customer satisfaction and subsequently to positive behavioural intentions [7]. It has been found that the perceived quality of airline services has a significant impact on passengers' satisfaction and consequently on perceived value, loyalty, airline image, behavioural intention, customer complaints, and word of mouth [26, 30, 31]. It has also been argued that perceived value may be an even better predictor of repurchase intention than either satisfaction or quality [7]. Hence, service quality and perceived value seem to be good predictors of repurchase intentions (expressed, in our research, through passenger recommendations), while the relationship between them still remains unclear [7].

Only a few researchers have studied the effect of perceived airline quality on recommendations of 
airline companies by passengers. Liu and Lee [32] found that as service quality increases, WOM and the willingness to recommend that to other users also increases. The improving service quality, for example, helps low-cost airlines build their market reputation, branding, and WOM recommendations for other passengers.

As already mentioned, the perceived quality of airline services has a significant impact on passengers' value perception and consequently on their behavioural intentions. Within our research WOM is understood as passengers' recommendations in the context of behavioural intention deriving from the perceived value for their money. WOM can contribute significantly to a firm's success in a variety of ways. Wangenheim and Bayón [33] analyzed the functional linkage between customer satisfaction, WOM, and new customer acquisition. They found that the satisfaction-WOM-new customer acquisition link can enrich the return on quality and satisfaction models. The value of word of mouth may be positive, neutral, or negative. Anderson [34] explained positive WOM as "the relating pleasant, vivid, or novel experiences; recommendations to others; and even conspicuous display. Negative WOM includes behaviours such as product denigration, relating unpleasant experiences, rumour, and private complaining." Söderlund and Rosengren [35] found that existing customers may have a significant impact on the potential customer, and that emotional variables play an important role in the influence process. Interpersonal relationships between customers and employees also have an important effect on WOM, because they are fostered to increase the likelihood of customer WOM behaviour [36]. A customer's recommendation is the result of satisfaction with services and their perceived reputation of an organization [37, 38]. Building on the above arguments, the passengers' airline recommendations can be seen as a reflection of the value they perceive and, according to the literature review, there is the hypothesis of the strong positive association between passengers' perceived value for their money and their airline recommendations. Based on the literature review, we contribute to the research area by testing the following hypotheses (Model I):

Hypothesis H1a. Perceived quality of in-flight airline services is positively related to the perceived value for money by passengers.

Hypothesis H1b. Perceived value for money is positively related to the passengers' recommendation of the airline company.

As the comfort of airline seats is a very important part of airline service quality and is comprised of several components like seat space, seat width, recline, legroom, flight duration etc., we decided to utilize another database in order to test (Model II) the relative importance of components of perceived airline seat comfort. Providing a seat that the passenger prefers is a component of tangibility (reliability and assurance safety) of airline service quality [4, 7, 39, 40, 41]. Past studies suggested that different aspects of airline seat comfort have an important impact on airline service quality perception. Rankin et al. [42] reported that longer flight duration contributes to decreased perceived overall comfort and especially to decreased perceived seat comfort. Gilbert and Wong [21] found that Japanese travellers have relatively higher expectations about comfortable seats as compared to others and that there are no significant differences between different types of passengers (i.e., business vs. leisure passengers). Espino et al. [43] described another aspect of seat comfort - having more legroom. Larger seat pitch is preferred by passengers (all other things being equal) as compared to less seat pitch. Also, the location of the seat in the plane has an important role, because location or selection of a seat is an important factor in passengers' evaluation and post-purchase decision making process [44]. Since airline seats are considered to be among the most important aspect of airline service quality perception, especially for the long distance flights, the following hypothesis is tested (Model II):

Hypothesis H2. Relative importance of components of perceived airline seat comfort for passengers on long-haul flights can be established.

\subsection{Conceptual model and hypotheses}

The conceptual model of our research is presented by Figure 1. It consists of two research Models (I and II) due to separate data bases and different statistical units of research, as explained later in the Methodology chapter.

\section{METHODOLOGY}

\subsection{Sample}

In our research databases, passengers from different countries who have used airline services of different airlines in the years 2014 and 2015 are included; data are accessible through the website Skytrax [45], where the databases are organized separately: for airline services reviewers - Database 1, while for seats reviewers - Database 2; therefore disabling the formation of a pooled sample. This is also the reason for two research models, as described above.

Database 1 - for testing hypotheses $\mathrm{H} 1 \mathrm{a}$ and $\mathrm{H} 1 \mathrm{~b}$ in Model I: reviewers of the airline services of three airlines are included into this analysis, that are comparable regarding the revenue and the number of passengers [46]; namely, according to the theory companies pursuing similar strategies with similar resource belong to the same strategic group $[47,48]$, therefore 


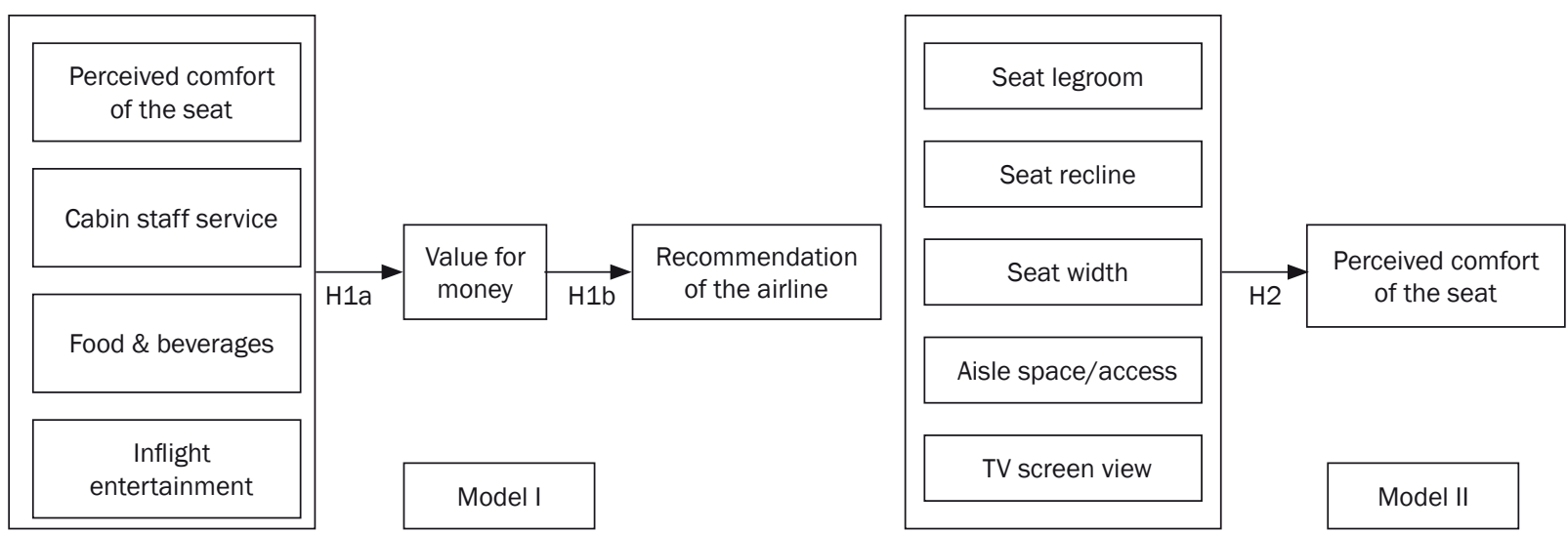

Figure 1 - Conceptual model of research

presenting the most suitable sample for analyzing the proposed research phenomena. A sample of $n=447$ passengers who used airline services of American Airlines, Lufthansa, and Emirates, and who were flying economy class, is utilized. Passengers evaluated the quality of individual in-flight components of the airline services via an online method.

Database 2 - for testing $\mathrm{H} 2$ in Model II: In accordance with Rankin et al. [42], emphasizing that the flight duration contributes to perceived seat comfort, $\mathrm{H} 2$ in Model II was tested only for passengers on long-haul flights. Those are according to Schawalden [49] flights lasting over 6 and up to 12 hours. The reason to study in more detail the components of passengers' perceptions of overall airline seat comfort on long-haul flights lies also in the fact that within the last five years alone, the number of flights over 6,000 nautical miles (13+ hours flight time) increased by $70 \%$, from 24 to 41 daily flights [50]. A sample of $n=244$ passengers on long-haul flights was used. The passengers evaluated the seats of the following airline companies, Lufthansa, American Airlines, Asiana, Austrian, British Airways, New Zealand, Australian Virgin, Virgin Atlantic, US Airways, and United Airlines. The passengers evaluated the components of seat comfort via an online method.

\subsection{Variables}

Model I refers to the study of the perceived quality of in-flight airline services, while Model II examined the perceived comfort of seats. The models include the following variables:

Model I: To test H1a, the observed predictor variables are perceived comfort of the seat, cabin staff service, food and beverages, and in-flight entertainment. The latter refers to the entertainment available to aircraft passengers during a flight. Since factors influencing the perception of the seat comfort (studied by Model II) are indirectly included in the perceived comfort of the seat that is the predictor variable in Model I, they are not explicitly included into this part of the analysis. The dependent variable is perceived value for money. All predictor variables of airline service quality were measured on a scale from 1 to 5 (1 - low quality; 5 - high quality). Perceived value for money is measured by the dichotomous variable, with value 0 low value and 1 - high value (recoding of the original values was performed - values 1-3 were recoded to 0 and 4-5 to 1). In $\mathrm{H} 1 \mathrm{~b}$, a variable recommendation of the airline company is measured by a dichotomous variable, with values 0 - no recommendation and 1 recommendation.

Model II: To verify H2, the following observed predictor variables were used: seat legroom, seat recline, seat width, TV screen view, and aisle space/access. Overall perceived seat comfort on long-haul flights is the dependent variable in Model II. All predictor variables of airline seat comfort at long-haul flights were measured on a scale from 1 to 5 (1 - low comfort; 5 - high comfort). The overall perceived seat comfort of the airline seat was measured by dichotomous variable, with values 0 - low comfort and 1 - high comfort (values 1-3 were recoded to 0 and values 4-5 to 1 ). Demographic variables for respondents are not reported.

\subsection{Methods}

With the purpose to test hypotheses $\mathrm{H} 1 \mathrm{a}, \mathrm{H} 1 \mathrm{~b}$ and $\mathrm{H} 2$, the binomial logistic regression models were used. The binomial logistic regression estimates the probability of an event happening, which in our research when testing hypotheses by Model I, is the probability of high perceived value ( $\mathrm{H} 1 \mathrm{a})$ and of recommendation of the airline company by a passenger $(\mathrm{H} 1 \mathrm{~b})$. With the purpose to test $\mathrm{H} 2$ of Model II, the binomial logistic regression model was used as well, but in this case the probability of high overall perceived comfort of the airline seat was assessed. The overall adequacy of the model was assessed by the percentage of correct predictions; Chi-square test $\left(\chi^{2}\right)$ and Nagelkerke $\mathrm{R}^{2}$. In order to test the significance of the individual regression coefficients, the Wald test with $p<0.10$ significance 
level is used. Also the $\operatorname{Exp}(\beta)$ - odds ratio - is reported, which represents the exponent of the regression coefficient. The odds ratio is the change in the odds of being in one of the outcome categories when the value of the predictor variable increases by one unit (coefficient B for the predictor variables are the natural logs of the odds ratio) [51]. For testing the hypotheses and for analysis of the results, the statistical support software IBM SPSS 21 was used.

\section{RESULTS}

Table 1 shows the results of the descriptive statistics (Mean \pm Standard deviation-SD) of Model I. The users of airline services assessed the cabin staff service (Mean=3.29 $\pm S D=1.562$ ) the highest, followed by in-flight entertainment (Mean=3.14 $\pm S D=1.572$ ). Seat comfort was assessed the lowest (Mean=3.10 $\pm S D=1.439$ ) along with food and beverages (Mean $=3.10 \pm S D=1.421$ ). In the sample, $58 \%$ of passengers report a high perception of value for money, while $59 \%$ of them would recommend the airline company.

Table 2 presents the results of the logistic regression model for testing $\mathrm{H} 1 \mathrm{a}$ and $\mathrm{H} 1 \mathrm{~b}$.

The model is significant, with approximately $85 \%$ of correct classification of the dichotomous dependent variable, significant Chi-square $\left(\chi^{2}\right)$ values, and over $66 \%$ and $53 \%$ of explained variance of the observed predictor variables (Nagelkerke $\mathrm{R}^{2}$ ), respectively. All predictor variables are significant at the $p<0.01$ level; the relationship is always positive, as expected; therefore, $\mathrm{H} 1 \mathrm{a}$ and $\mathrm{H} 1 \mathrm{~b}$ are justified.

Table 1 - Descriptive statistics for Model I

\begin{tabular}{||l|c|c||}
\hline \multicolumn{1}{|c|}{ Variables } & Mean & \pm SD \\
\hline \hline Seat comfort & 3.10 & 1.439 \\
\hline Cabin staff service & 3.29 & 1.562 \\
\hline Food and beverages & 3.10 & 1.421 \\
\hline In-flight entertainment & 3.14 & 1.572 \\
\hline Value for money & 0.58 & 0.494 \\
\hline Recommendation & 0.59 & 0.492 \\
\hline
\end{tabular}

When assessing the odds for high perceived value for money, the two most influential factors are revealed to be seat comfort and cabin staff services, followed by the perceived quality of food and beverages and inflight entertainment. When assessing the odds for recommendation of the airline company, perceived value for money is an important predictor; if a passenger perceives high value for money, then they are much more likely to recommend that airline in comparison to those who perceive low value for money, as expected.

Table 3 shows the descriptive statistics for Model II. The passengers on long-haul flights assessed the comfort components of airline seats. High marks were given to the TV screen view component (Mean=2.79 $\pm \mathrm{SD}=1.328)$, seat recline (Mean $=2.48 \pm \mathrm{SD}=1.265$ ) and seat legroom (Mean=2.47 $\pm S D=1.486$ ) component. The lowest marks given by the users were to the aisle space/ access (Mean $=2.44 \pm S D=1.420$ ) and the seat width (Mean $=2.44 \pm S D=1.267$ ). Only $29 \%$ of passengers assessed the overall comfort as high.

Binomial logistic regression results are presented in Table 4. Overall, the model is highly significant, with almost $95 \%$ of correct classifications of dependent dichotomous variable, significant $\chi^{2}$, and approximately $86 \%$ of explained variance of the observed variables (Nagelkerke, $\mathrm{R}^{2}$ ).

All the observed variables are important when estimating the prevalence of high overall perceived airline seat comfort; all relationships are positive. Research results revealed that the most important aspect is the

Table 3 - Descriptive statistics for Model II

\begin{tabular}{|l|c|c||}
\hline \multicolumn{1}{|c|}{ Variables } & Mean & \pm SD \\
\hline \hline Seat legroom & 2.47 & 1.486 \\
\hline Seat recline & 2.48 & 1.265 \\
\hline Seat width & 2.44 & 1.267 \\
\hline TV screen view & 2.79 & 1.328 \\
\hline Aisle space/room & 2.44 & 1.420 \\
\hline $\begin{array}{l}\text { Overall comfort } \\
\text { of the airline seat }\end{array}$ & 0.29 & 0.455 \\
\hline
\end{tabular}

Table 2 - Binomial logistic regressions for Model I

\begin{tabular}{|c|c|c|c|c|c|c|}
\hline Dependent variable & Observed variables & $\mathrm{B}$ & S.E. & Wald & Sig. & $\operatorname{Exp}(\beta)$ \\
\hline \multirow{6}{*}{$\begin{array}{l}\text { Perceived } \\
\text { value for money }\end{array}$} & Seat comfort & 0.893 & 0.130 & 46.890 & 0.000 & 2.442 \\
\hline & Cabin staff service & 0.740 & 0.125 & 35.110 & 0.000 & 2.097 \\
\hline & Food and beverages & 0.634 & 0.146 & 18.936 & 0.000 & 1.885 \\
\hline & Inflight entertainment & 0.282 & 0.114 & 6.090 & 0.014 & 1.326 \\
\hline & Constant & -8.068 & 0.809 & 174.338 & 0.000 & 0.000 \\
\hline & \multicolumn{6}{|c|}{ Model $\chi^{2}=300.680(p<0.01) ;$ Nagelkerke $\mathrm{R}^{2}=0.663, \%$ of corr. class. $=85.1 \%$} \\
\hline Dependent variable & Observed variables & B & S.E. & Wald & Sig. & $\operatorname{Exp}(\beta)$ \\
\hline \multirow{3}{*}{ Recommendation } & Perc. value for money & 3.545 & 0.303 & 136.814 & 0.000 & 34.655 \\
\hline & Constant & -0.817 & 0.159 & 26.372 & 0.000 & 0.442 \\
\hline & \multicolumn{6}{|c|}{ Model $\chi^{2}=213.758(p<0.01) ;$ Nagelkerke $\mathrm{R}^{2}=0.531, \%$ of corr. class. $=83.7 \%$} \\
\hline
\end{tabular}


Table 4 - Binomial logistic regression for Model II

\begin{tabular}{||l|l|c|c|c|c|c||}
\hline \hline Dependent variable & \multicolumn{1}{|c|}{ Observed variables } & B & S.E. & Wald & Sig. & $\operatorname{Exp}(\beta)$ \\
\hline \hline \multirow{4}{*}{$\begin{array}{l}\text { Overall comfort } \\
\text { of the airline seat }\end{array}$} & Seat legroom & 0.910 & 0.388 & 5.506 & 0.019 & 2.485 \\
\cline { 2 - 8 } & Seat recline & 0.753 & 0.379 & 5.935 & 0.047 & 2.123 \\
\cline { 2 - 8 } & Seat width & 1.121 & 0.356 & 9.896 & 0.002 & 3.068 \\
\cline { 2 - 8 } & Aisle space/access & 0.614 & 0.334 & 3.385 & 0.066 & 1.848 \\
\cline { 2 - 8 } & TV screen view & 0.648 & 0.298 & 4.729 & 0.030 & 1.913 \\
\cline { 2 - 8 } & Constant & -13.205 & 2.090 & 39.907 & 0.000 & 0.000 \\
\hline
\end{tabular}

seat width component. The odds ratio for seat width shows that changes to this predictor variable per one unit contribute to over 3 times greater odds to high overall perceived airline seat comfort, while seat legroom was revealed to be the next most important component of the overall perceived airline seat comfort. The significant importance of seat recline, TV screen view and aisle space/access was also confirmed; therefore, support has been provided for $\mathrm{H} 2$.

\section{DISCUSSION}

Based on the literature review it has been established that the determinants influencing the perceived airlines service quality changes when travelling with different airline companies. Characteristics of environment and changes due to globalization are shaping the travellers' general needs and passengers' personalized demands. Our research aims to contribute to the contemporary understanding of the specific inflight service quality determinants and their impact on passengers' perceived value for their money, followed by their recommendations as well as perceived comfort of the airline seats.

Our results are in line with some reports in literature, where perceived comfort with the airline seat is the most important factor of customers' satisfaction with the airline services [7, 9, 40, 41]. Our research results namely, reveal that perceived seat comfort and cabin staff services are the most important influential factors in relation to their perceived value for money. The odds of customers' perceived high value for money regarding airline services is almost 2.5 times greater with a unit increase in seat comfort assessment and 2.1 times greater with a unit increase of the perceived quality of cabin staff services. Additionally, those who perceive high value are almost 35 times as likely to recommend the airline company, as compared to those who perceive a low value.

Past studies report that seat width is the most important factor of passengers' overall comfort in an aircraft [52, 50]; our research results confirmed that on long-haul flights the seat width is significant, while the perceived comfort of seat legroom is the second most important contributor to the perceived overall comfort of the airline seat. Our results are therefore also in line with the results of Espino et al. [43], who found passengers' preference for a larger seat pitch. Although the database limitation does not allow us to differentiate analysis regarding the cabin in which the passenger flew, as only economy class passengers were included in this research, our results are important for the airline industry and for the strategies regarding incraft airline services development.

\section{CONCLUSION}

This study found that seat comfort presents the most influential factor when speaking about perceived value for money, which highly influences passengers' recommendations. As such, this factor needs to be given appropriate strategic reconsideration. Further, our research also revealed that for the long-haul flights seat width and seat legroom are the two most important factors of passengers' overall seat comfort perception in an aircraft, followed by seat recline, TV screen view and aisle space/access, all of them also significantly important, when assessing the perceived airline seat comfort.

Our findings are in accordance with future expectations claiming that the number of passengers flying over longer distances is increasing and is expected to increase even more in the future. Therefore, it can be expected that seat comfort will become even more important.

The study still has some limitations. They are mainly associated with the availability of data. The pooled sample of passengers (reviewers) assessing the airline services and seat comfort components could enable more in-depth analysis of factors influencing the passengers' airline recommendations. Therefore, the development of refined and comprehensive inflight airline service quality instruments based on the current research findings might allow for a deeper understanding of the topic. We are also aware of the many facts that could enrich the understanding of the 
investigated phenomena and could be included into an extended multiple conceptual model. For example, the cabin in which the passenger flew may have an impact on research results, but trends in the airline industry regarding this area are also changing. Some forecasts reveal that the improvement of comfort when flying in economy class are more and more important [50], thus implying that differences between economy and other cabin classes may be very likely diminishing in the future. Passenger demographic features might present an interesting path of further investigation, including the comparison between different types of passengers (business vs. leisure), low-cost versus full service carriers, because low-cost carriers share in passenger traffic is getting higher each year [53] etc.

Airline company image may also have an impact on the assessment of service quality. Some research results suggest that the airline's corporate image may be associated with the passengers' expectations toward in-flight services [54]. This is an important possible enhancement to our research, as the airline company image may have an effect on passengers' predetermination about the overall comfort of the flight experience. This was not taken into account in the current research.

\section{Doc. Dr. URBAN ŠEBJAN ${ }^{1}$}

E-mail: urban.sebjan@um.si

Prof. Dr. POLONA TOMINC ${ }^{1}$

E-mail: polona.tominc@um.si

Prof. Dr. KARIN ŠIREC ${ }^{1}$

E-mail: karin.sirec@um.si

${ }^{1}$ Univerza v Mariboru, Ekonomsko-poslovna fakulteta

Razlagova 14, 2000 Maribor, Slovenia

\section{MULTIPLI KONCEPTUALNI MODEL ZAZNANE KAKOVO- STI LETALSKIH STORITEV MED LETOM}

\section{POVZETEK}

Kljub obsežni literaturi o različnih vidikih kakovosti letalskih storitev $v$ povezavi $z$ vedenjskimi namerami potnikov, so bili nekateri posebni vidiki kakovosti letalskih storitev med samim letom $v$ preteklosti deležni manjše pozornosti. Tako je $v$ ospredju pričujoče raziskave multipli konceptualni model zaznane kakovosti letalskih storitev med letom, v povezavi z zaznano vrednostjo s strani potnikov, kateri sledi priporočilo ("od ust do ust") letalske družbe, kot tudi udobje ter zaznana kakovost letalskih sedežev. Raziskava temelji na dveh podatkovnih bazah, ki vsebujejo mnenja potnikov o zaznani kakovosti letalskih storitev med letom ter o udobnosti letalskih sedežev. Rezultati raziskave kažejo, da je zaznana kakovost letalskih sedežev s strani potnikov, najpomembnejši dejavnik zaznane kakovosti letalskih storitev med letom, ki hkrati znatno vpliva na zaznano vrednost storitve ter posledično oblikuje vedenjske namere ( $v$ naši raziskavi izražene s pozitivnim priporočilom "od ust do ust"). Analiza relativne pomembnosti posameznih komponent zaznane kakovosti letalskih sedežev pa kaže, da je širina sedeža najpomembnejši dejavnik, ki prispeva k celokupnemu zaznanemu udobju letalskega sedeža.

\section{KLJUČNE BESEDE}

kakovost letalskih storitev med letom; zaznana vrednost; priporočilo ("od ust do ust"); udobnost letalskih sedežev;

\section{REFERENCES}

[1] Bogicevic V, Yang W, Bilgihan A, Bujisic M. Airport service quality drivers of passenger satisfaction. Tourism Review. 2013;68(4):3-18. doi: http://dx.doi. org/10.1108/TR-09-2013-0047

[2] IATA - The International Air Transport Association. Strong Traffic Growth Continues in May. 2015. [cited 2016 Jan 10] Available from: http://www.iata.org/ pressroom/pr/Pages/2015-07-02-01.aspx.

[3] IATA - The International Air Transport Association. Strong Demand Growth Returns in November. 2017. [cited 2017 Jan 11] Available from: http://www.iata. org/pressroom/pr/Pages/2017-01-11-01.aspx.

[4] Park J-W, Robertson R, Wu C-L. The effect of airline service quality on passengers' behavioral intentions: a Korean case study. Journal of Air Transport Management. 2004;10:435-439. doi: 10.1016/j.jairtraman.2004.06.001

[5] Park J-W, Robertson R, Wu C-L. Investigating the effects of airline service quality on airline image and passengers' future behavioral intentions: findings from Australian international air passengers. Journal of Tourism Studies. 2005;16(1):1035-4662.

[6] Park J-W, Wu C-L. Modelling the Impact of Airline Service Quality and Marketing Variables on Passengers' Future Behavioural Intentions. Transport Planning and Technology. 2006;29(5):359-381. doi: 10.1080/03081060600917686

[7] Chen C-F. Investigating structural relationships between service quality, perceived value, satisfaction, and behavioral intentions for air passengers: Evidence from Taiwan. Transportation Research Part A: Policy and Practice. 2008;42(4):709-717. doi: 10.1016/ j.tra.2008.01.007

[8] Saha GC, Theingi T. Service quality, satisfaction, and behavioral intentions. A study of low-cost airline carriers in Thailand. Managing Service Quality. 2009;19(3):350-372. doi: http://dx.doi. org/10.1108/09604520910955348

[9] Chen F-Y, Chang Y-H. Examining airline service quality from a process perspective. Journal of Air Transport Management. 2005;11(2):79-87. doi: 10.1016/ j.jairtraman.2004.09.002

[10] Chou C-C, Liu L-J, Huang S-F, Yin J-M, Han T-C. An evaluation of airline service quality using the fuzzy weighted SERVQUAL method. Applied Soft Computing 2011;11(2):2117-2128. doi: 10.1016/ j.asoc.2010.07.010

[11] Grönroos C. A service quality model and its marketing implications. European Journal of Marketing. 1984;18(4):36-44. doi: http://dx.doi.org/10.1108/ EUM0000000004784

[12] Parasuraman A, ZeithamI VA, Berry LL. A conceptual model of service quality and its implications for future 
research. Journal of Marketing. 1985;49(4):41-50.

[13] Grönroos C. Service Quality: The Six Criteria Of Good Perceived Service. Review of Business. 1988;9(3): 10-13.

[14] Haywood-Farmer J. A Conceptual Model of Service Quality. International Journal of Operations \& Production Management. 1989;8(6):19-29. doi: http:// dx.doi.org/10.1108/eb054839

[15] Bruhn M, Georgi D. Services Marketing. Managing The Service Value Chain. Person: Harlow; 2006.

[16] Kotler P, Keller KL, Brandy M, Goodman M, Hansen T. Marketing Management. Person: Harlow; 2009.

[17] Paparoidamis NG, Chumpitaz R, Ford J. Service quality, Customer Satisfaction, Value and Loyalty. An Empirical Investigation In A Service Failure Context. Marketing Dynamism \& Sustainability: Things Change, Things Stay the Same...Springer: New York; 2012.

[18] Aaker DA, McLoughlin D. Strategic Market Management. Global Perspectives. John Wiley \& Sons: Chichester; 2010.

[19] Rhoades DL. Evaluation of International Aviation. 2014. Ashgate: Hampshire.

[20] Kossmann M. Delivering Excellent Service Quality in Aviation: A Practical Guide for Internal and External Service Providers. Ashgate: Hampshire; 2006.

[21] Gilbert D, Wong RKC. Passenger expectations and airline services: a Hong Kong based study. Tourism Management. 2003;24:519-532. doi: 10.1016/S02615177(03)00002-5

[22] Jou R-C, Lam S-H, Hensher DA, Chen CC, Kuo CW. The effect of service quality and price on international airline competition. Transportation Research Part E: Logistics and Transportation Review. 2008;44(4):580592. doi: 10.1016/j.tre.2007.05.004

[23] Wittmer A, Bieger T, Müller R. Aviation Systems: Management of the Integrated Aviation Value Chain. Springer: London; 2011.

[24] Yang K-C, Hsieh T-C, Li H, Yang C. Assessing how service quality, airline image and customer value affect the intentions of passengers regarding low cost carriers. Journal of Air Transport Management. 2012;20:52-53. doi: 10.1016/j.jairtraman.2011.12.007

[25] Namukasa J. The influence of airline service quality on passenger satisfaction and loyalty: The case of Uganda airline industry. The TQM Journal. 2013;25(5):520532. doi: http://dx.doi.org/10.1108/TQM-11-20120092

[26] Suki NM. Passenger satisfaction with airline service quality in Malaysia: A structural equation modeling approach. Research in Transportation Business \& Management. 2014;10:26-32. doi: 10.1016/ j.rtbm.2014.04.001

[27] Kuo C-W, Jou R-C. Asymmetric response model for evaluating airline service quality: An empirical study in cross-strait direct flights. Transportation Research Part A: Policy and Practice. 2014;62:63-70. doi: 10.1016/ j.tra.2014.02.004

[28] Hussain R, Nasser AA, Hussain YK. Service quality and customer satisfaction of a UAE-based airline: An empirical investigation. Journal of Air Transport Management. 2015;42:167-175. doi: 10.1016/ j.jairtraman.2014.10.001

[29] Leong L-Y, Hew T-S, Lee V-H, Ooi K-B. An
SEM-artificial-neural-network analysis of the relationships between SERVPERF, customer satisfaction and loyalty among low-cost and full-service airline. Expert Systems with Applications. 2015;42:6620-6634. doi: 10.1016/j.eswa.2015.04.043

[30] Nikookar G, Rahrovy E, Razi S, Ghassemi RA. Investigating Influential Factors on Word of Mouth in Service Industries: The Case of Iran Airline Company. Procedia - Social and Behavioral Sciences. 2015;177:217-222. doi: 10.1016/j.sbspro.2015.02.392

[31] Widianti T, Sumaedi S, Bakti IGMY, Rakhmawati T, Astrini NJ, Yarmen M. Factors influencing the behavioral intention of public transport passengers. International Journal of Quality \& Reliability Management. 2015;32(7):666-692. doi: http://dx.doi.org/10.1108/ IJQRM-01-2013-0002

[32] Liu CHS., Lee T. Service quality and price perception of service: Influence on word-of-mouth and revisit intention. Journal of Air Transport Management. 2016;52:4254. doi: 10.1016/j.jairtraman.2015.12.007

[33] Wangenheim FV, Bayón T. The chain from customer satisfaction via word-of-mouth referrals to new customer acquisition. Journal of the Academy of Marketing Science. 2007;35(2):233-249.

[34] Anderson EW. Customer satisfaction and word of mouth. Journal of service research. Journal of Service Research. 1998;1(1):5-17. doi: 10.1177/109467059800100102

[35] Söderlund M, Rosengren S. Receiving word-of mouth from the service customer: An emotion-based effectiveness assessment. Journal of retailing and consumer services. 2007;14(2):123-136. doi: 10.1016/ j.jretconser.2006.10.001

[36] Gremler DD, Gwinner KP, Brown SW. Generating positive word-of-mouth communication through customer-employee relationships. International Journal of Service Industry Management. 2001;12(1):44-59. doi: http://dx.doi.org/10.1108/09564230110382763

[37] Arasli H, Mehtap-Smadi S, Turan Katircioglu S. Customer service quality in the Greek Cypriot banking industry. Managing Service Quality. 2005;15(1):41-56. doi: http://dx.doi.org/10.1108/09604520510575254

[38] Bontis N, Booker LD, Serenko A. The mediating effect of organizational reputation on customer loyalty and service recommendation in the banking industry. Management Decision. 2007;45(9):1426-1445. doi: http://dx.doi.org/10.1108/00251740710828681

[39] Elliott K, Roach DW. Service quality in the airline industry: are carriers getting an unbiased evaluation from consumers? Journal of Professional Service Marketing. 1993;9(2):71-82. doi: 10.1300/J090v09n02_06

[40] Pakdil F, Aydın Ö. Expectations and perceptions in airline services: An analysis using weighted SERVQUAL scores. Journal of Air Transport Management. 2007;13:229-237. doi: 10.1016/ j.jairtraman.2007.04.001

[41] De Jager JW, Van Zyl D, Toriola AL. Airline service quality in South Africa and Italy. Journal of Air Transport Management. 2012;25:19-21. doi: 10.1016/ j.jairtraman.2012.04.002

[42] Rankin WL, Space DR, Nagda NL. Passenger comfort and the effect of Air Quality. In: Nagda NL, editor. Air Quality and Comfort in Airlines cabins. ASTM STP1393. 
West Conshohocken, PA: American Society for Testing and Materials; 2000.

[43] Espino R, Martin JC, Roman C. Analyzing the effect of preference heterogeneity on willingness to pay for improving service quality in an airline choice context. Transportation Research Part E: Logistics and Transportation Review. 2008;44(4):593-606. doi: 10.1016/j.tre.2007.05.007

[44] Han H. Effects of in-flight ambience and space/function on air travelers' decision to select a low-cost airline. Tourism Management. 2013;37:125-135. doi: 10.1016/j. tourman.2013.01.008

[45] Skytracks. Latest airline Reviews. 2015. [cited 20 December 2015] Available from: http://www.airlinequality. com/main/forum.htm. 2015.

[46] World Airline Rankings, Airline Business. 2015;31(6):3541.

[47] Porter ME. The Structure within Industries \& Companies' Performance. Review of Economics \& Statistics. 1979;61(2):214-227.

[48] Porter ME. Competitive Strategy: Techniques for Analyzing Industries \& Competitors. Free Press: N-Y;1980.
[49] Schawalden J. The future of Inflight Entertainment in Europe, according to passengers expectatations. Hamburg: Anchor Academic Publishing; 2015.

[50] Airbus. The future laboratory: the future of comfort; 2014. Available from: http://www.airbus.com/aircraftfamilies/comfort/. 2015 [accessed 2015 Dec 14].

[51] Tabachnick BG, Fidell LS. Using Multivariate Statistics. Boston etc.: Pearson; 2013.

[52] Lu J-L, Tsai L-N. Modelling the effect of enlarged seating room on passenger preferences of domestic airlines in Taiwan. Journal of Air Transportation. 2004;9(2):83-96

[53] Pavlin S, Dimnik I, Starčević M. Influence of low-cost carriers on airport infrastructure development. Promet - Traffic - Traffico. 2007;19(1):49-54.

[54] Ariffin AAM, Nameghi ENM, Khakizadeh A. The relationship between Airlines' corporate image and the expectation toward inflight hospitality services. Academic Journal of Interdisciplinary studies. 2013;2(11):179185. doi: 10.5901/ajis.2013.v2n11p179 